\title{
Wong Solo Restaurant Service As A Provider Of Processed Chicken Meat To Customer Satisfaction
}

\author{
Natsir Sandiah ${ }^{1}$, Wa Reni ${ }^{1}$, La Ode Arsad Sani ${ }^{1}$, La Ode Muh Munadi ${ }^{1}$ \\ ${ }^{1}$ Faculty of Animal Husbandry, Halu Oleo University, Kendari City, Southeast Sulawesi \\ Email: arsadsani@uho.ac.id
}

(Accepted: 12 Februari 2021; Approved: 21 April 2021; Published: 28 Mei 2021)

\begin{abstract}
The development of poultry farming business is increasing rapidly and contributes greatly in the fulfillment of protein needs. The business sector of processed chicken meat such as cafes, restaurants, and restaurants and sea food to meet the needs of consumers. The research aims to analyze the type of service in influencing the satisfaction of consumers of Wong Solo Kendari Branch by using survey methods and using accidental sampling techniques as many as 60 respondents. It is then analyzed using multiple linear regression tests. The results showed physical evidence, reliability, responsiveness, service assurance, and caring together have a very real effect on consumer satisfaction $(\mathrm{p}<0.01)$ in Wong Solo restaurants and factors that correlate positively to customer satisfaction are responsiveness, service assurance and care, while variables that correlate negatively to consumer satisfaction are physical evidence and reliability. Variable concern partially affects consumer satisfaction $(\mathrm{P}<0.01)$.
\end{abstract}

Keyword: Restaurant, Processed Meat, Consumer

\section{INTRODUCTION}

The development of poultry farming business is now increasing rapidly and contributes greatly in the fulfillment of protein needs, especially animal origin proteins. Poultry, especially chicken, is one of the commodities that are in great demand by all walks of life. Livestock business in Southeast Sulawesi, especially the production of chicken meat buras ranked the highest at $10,135,731$ tons or $69.31 \%$ compared to the production of broiler chicken meat 4,486,419 tons or $30.68 \%$ of the total chicken meat production of 14.622150 tons. In contrast, the production of chicken meat in Kendari city is smaller by 254,296 tons or $13.78 \%$ compared to the production of broiler chicken meat is higher by $1.592,903$ tons or $86.23 \%$ of total chicken meat production of $1,847,199$ tons in 2013 (Statistics agency, 2014).

Satisfaction is the level of feeling after comparing performance or perceived results with expectations (Sumarwan, 2003). Consumer satisfaction is a person's feelings of pleasure or disappointment that arise after comparing the perception of a product's performance with its expectations. Wong Solo restaurant was founded by Puspo Wardoyo first in 1991 in Medan City, and entered in Kendari City around 2012, located on Brigjend M. Yoenoes street. Wong Solo's signature menu is grilled chicken and fried chicken. The method of service by ordering a dish or food menu directly according to the tastes of consumers at the restaurant salesman or through the order of the rice box party. The interesting thing that is reviewed from the management of Wong Solo restaurant is the quality of service that remains guaranteed because it always collects information or advice through feedback from its customers directly and in writing.

Based on the background description, the problem studied in the study is what services affect the satisfaction of the restaurant coumen Wong Solo Kendari Branch with the aim of the study to analyze the type of service affects the satisfaction of 
consumers Wong Solo Kendari branch The benefit of this research is to be able to distinguish which ways of thinking creatively by utilizing business opportunities related to processed chicken meat, obtain information (feed back) comfort and waiters in Wong Solo restaurant so that consumers can determine the right choice of place to eat according to taste and attractive and restaurant owners can be used as capital on the importance of applying quality of service for employees to increase sales and attract consumers as much as possible.

\section{RESEARCH METHODS}

The research was conducted at Wong Solo Kendari Branch restaurant located on Jl. Brig. Gen. M. Yoenoes No. 128, Kendari, Southeast Sulawesi in January 2021. The method of research in the form of surveys by taking data by accidental sampling technique is to determine respondents by chance, or anyone if the person is considered a consumer and can provide information related to his research by using questionnaires. The number of respondents taken as many as 60 people. The data analysis found the quality factors of Wong Solo's restaurant service to customer satisfaction using multiple linear regression tests. To find out two or more free variables Table 1. Respondent Characteristics by Gender against related variables that will be calculated by the following equation:

$$
\begin{array}{ll}
\mathrm{Y}=\mathrm{a}+\mathrm{b}_{1} \mathrm{X}_{1}+\mathrm{b}_{2} \mathrm{X}_{2}+\ldots . . \mathrm{b}_{5} \mathrm{X}_{5}+\mathrm{e} \\
\mathrm{Y} & =\text { Customer Satisfaction } \\
\mathrm{A} & =\text { Kostanta } \\
\mathrm{b} 1, \mathrm{~b} 2, \ldots . \mathrm{b} 5 & =\text { Regression coefficient } \\
\mathrm{X}_{1} & =\text { Physical evidence } \\
\mathrm{X}_{2} & =\text { Reliability } \\
\mathrm{X}_{3} & =\text { Capture power } \\
\mathrm{X}_{4} & =\text { Service guarantee } \\
\mathrm{X}_{5} & =\text { Concern } \\
\mathrm{e} & =\text { Error rate (error experiment) }
\end{array}
$$

\section{RESULTS AND DISCUSSION}

\section{Characteristics of Respondents}

Based on the results of data collection obtained through questionnaires. Presentation of data on the identity of the respondent here, namely to give an idea of the state of the respondent. The description of respondents who were sampled in this study is based on gender, age, education, occupation, family dependents, and income. Gender is an indicator that affects the consumption of a product or service in a stall or restaurant. Gender differences have a real effect on the level of consumption of product. Respondents by gender can be seen in Table 1 .

\begin{tabular}{lcc}
\hline Respondents & Total (Orang) & Percentase \\
\hline Male & 28 & 46,7 \\
Female & 32 & 53,3 \\
\hline Total & $\mathbf{6 0}$ & $\mathbf{1 0 0}$ \\
\hline
\end{tabular}

Source: Processed primary data, 2021

Wong Solo restaurant consumers by gender were $53.3 \%$ female compared to $46.7 \%$ of the total 60 respondents. This is a woman who comes in Wong Solo restaurant usually in groups, in contrast to male consumers who come alone and tend to men more activities outside than to go eat with her friends.

\section{Age}

The age of a person will cause a change in the type of goods and services they buy as a result of changes in the needs of life. Age can affect a person's taste for a product or service. Respondents by age can be seen in Table 2.

Table 2. Characteristics of Respondents By Age

\begin{tabular}{lcc}
\hline Age (Year) & Total (Person) & Percentase $(\%)$ \\
\hline $10-19$ & 2 & 3,33 \\
$20-29$ & 18 & 30 \\
$30-39$ & 30 & 50 \\
$40-49$ & 5 & 8,33
\end{tabular}


Source: Processed primary data, 2021

Between 20 - 39 years old, wong solo restaurant visits are $80 \%$ compared to between 10-19 years old and between 40-60 years old by $20 \%$. These are people who are between the ages of 20-39 years old who have worked as employees who have a sufficient income compared to those between the ages of 10-19 years. Between 40-60 years old they have more health and more time at home.

\section{Education Level}

The level of education will affect the mindset of consumers, especially the purchasing power of goods and services for daily needs and have a wide knowledge of the development of goods and services. This can be seen in Table 3.

Table 3. Characteristics of Respondents By Education Level

\begin{tabular}{lcc}
\hline Education & Total (Person) & Percentase $(\boldsymbol{\%})$ \\
\hline SLTP & 1 & 1,7 \\
SLTA & 17 & 28,3 \\
S1 & 42 & 70 \\
\hline Total & $\mathbf{6 0}$ & $\mathbf{1 0 0}$ \\
\hline
\end{tabular}

Source: Processed primary data, 2021

The results showed that Wong Solo restaurant customers Kendari branch has more professions as scholars compared to consumers who have the level of education jss and senior high school. This has an effect on the mindset and knowledge of consumers, the development of goods and services. As well as will affect the level of income of a person.

\section{Work}

Work is one of the factors that influence a person's buying pattern. A person has a different job than others will certainly have a pattern of consumption of a product will also be different both in terms of type and in terms of quantity. Respondents based on the type of work are seen in Table 4.

Table 4. Respondent Characteristics By Job Type

\begin{tabular}{lcc}
\hline Work & Total (Person) & Percentase (\%) \\
\hline PNS & 25 & 41,7 \\
Private Employees & 22 & 36,7 \\
Self employed & 8 & 13,33 \\
Student/Student & 5 & 8,33 \\
\hline Total & $\mathbf{6 0}$ & $\mathbf{1 0 0}$ \\
\hline
\end{tabular}

Source: Processed primary data, 2021

Wong Solo restaurant consumers are more employees, namely $78.4 \%$ consisting of civil servants and private employees, compared to others, namely $21.6 \%$ consisting of the selfemployed, and students or students. This is a consumer visitor to Wong Solo restaurant is among people who already work in the employee sector is a potential on wong solo restaurant service products, as well as employees more work outside the house, so there is no time to return home for lunch and tend to choose food outside.

\section{Income Level}

Revenue is one of the important factors to increase goods and services. If you have a high income, the desire to eat outside will also be high and will affect the level of consumption patterns of goods and services. Level of consumer income in this study can be seen in Table 5 . 
Table 5. Respondent Characteristics By Income

\begin{tabular}{lcc}
\hline \multicolumn{1}{c}{ Income } & Total (Person) & Percentase (\%) \\
\hline$<$ Rp 500.000,- & 3 & 5 \\
Rp.500.000,- -Rp.990.000,- & 5 & 8,33 \\
Rp.1.000.000,- - Rp. 2.000.000,- & 7 & 11,67 \\
$>$ Rp. 2.000.000,- & 45 & 75 \\
\hline Total & $\mathbf{6 0}$ & $\mathbf{1 0 0}$ \\
\hline
\end{tabular}

Source: Processed primary data, 2021

Consumer income based on Table 5 that many visited Wong Solo restaurant Kendari City is a relatively high income of $75 \%$ compared to low incomes ranging from $5 \%$. Consumer income can be used as a benchmark for manufacturers and marketers to market their products.

\section{Level of Service to Customer Satisfaction}

One of the efforts made to support customer satisfaction, especially companies engaged in services is to provide the application of quality of service, because improving the quality of service can affect customer satisfaction. Improving the level of service of Wong Solo restaurant management Table 6. Consumer Responses to Physical Evidence (Tangible)

\begin{tabular}{|c|c|c|c|c|c|c|c|c|c|}
\hline \multirow{2}{*}{ No } & \multirow{2}{*}{ Questions } & \multicolumn{5}{|c|}{ Score } & \multirow{2}{*}{ Total } & \multirow{2}{*}{ Average } & \multirow{2}{*}{ Information } \\
\hline & & SP & $\mathbf{P}$ & $\mathbf{S}$ & TP & STP & & & \\
\hline 1. & $\begin{array}{l}\text { Is the building and room } \\
\text { nice and interesting }\end{array}$ & 8 & 47 & 4 & 1 & 0 & 242 & 4,03 & Puas \\
\hline 2 & $\begin{array}{l}\text { Is the parking lot spacious } \\
\text { and safe }\end{array}$ & 28 & 30 & 2 & 0 & 0 & 266 & 4,43 & Sangat puas \\
\hline 3 & $\begin{array}{l}\text { Do employees look clean } \\
\text { and tidy and attractive }\end{array}$ & 10 & 45 & 5 & 0 & 0 & 245 & 4,08 & Puas \\
\hline 4. & $\begin{array}{l}\text { Is the arrangement of the } \\
\text { room clean neat and } \\
\text { comfortable }\end{array}$ & 9 & 49 & 2 & 0 & 0 & 247 & 4,12 & Puas \\
\hline 5. & $\begin{array}{l}\text { Whether the food menu is } \\
\text { appetizing }\end{array}$ & 6 & 49 & 5 & 0 & 0 & 241 & 4,02 & Puas \\
\hline & $\begin{array}{l}\text { Total } \\
\text { Average }\end{array}$ & & & & & & & $\begin{array}{c}20,68 \\
4,14\end{array}$ & Puas \\
\hline
\end{tabular}

Source: Processed primary data, 2021 to consumers, the service quality analysis is carried out. The dimensions of service quality are: tangibles, reliability, responsiveness, service assurance, emphaty.

\section{Consumer Response Index on Physical Evidence (Tangible)}

Physical evidence (tangible) shows the ability of the location in showing its existence to external parties. The condition of equipment, buildings and physical equipment is a form of concrete evidence of the possibility of high quality of service provided response to tangible can be seen in Table 6 . by Wong Solo restaurant. The results of the

\section{Consumer Response Index on Responsiveness}

Responsiveness is the provision of service to customers quickly and responsively. The response result to the responsiveness variable can be described in Table 7. 
Table 7. Consumer Response to Responsiveness

\begin{tabular}{|c|c|c|c|c|c|c|c|c|c|}
\hline \multirow{2}{*}{ No } & \multirow{2}{*}{ Questions } & \multicolumn{5}{|c|}{ Score } & \multirow{2}{*}{ Total } & \multirow{2}{*}{ Average } & \multirow{2}{*}{ Information } \\
\hline & & SP & $\mathbf{P}$ & S & TP & STP & & & \\
\hline 1. & $\begin{array}{l}\text { Do employees catch } \\
\text { consumer complaints }\end{array}$ & 3 & 26 & 29 & 2 & 0 & 213 & 3,55 & Puas \\
\hline 2 & $\begin{array}{l}\text { Whether employees are } \\
\text { always quick to serve and } \\
\text { help consumers or guests }\end{array}$ & 3 & 47 & 10 & 0 & 0 & 233 & 3,88 & Puas \\
\hline 3 & $\begin{array}{l}\text { Are employees quick to solve } \\
\text { problems }\end{array}$ & 2 & 19 & 34 & 5 & 0 & 198 & 3,27 & Sedang \\
\hline 4. & $\begin{array}{l}\text { Are employees always quick } \\
\text { in handling consumer } \\
\text { transactions }\end{array}$ & 35 & 20 & 5 & 0 & 0 & 270 & 4,50 & Sangat puas \\
\hline 5. & $\begin{array}{l}\text { What is the employee's } \\
\text { perseverness to help } \\
\text { consumers }\end{array}$ & 0 & 42 & 18 & 0 & 0 & 222 & 3,70 & Puas \\
\hline & $\begin{array}{l}\text { Total } \\
\text { Average }\end{array}$ & & & & & & & $\begin{array}{l}18,9 \\
3,78\end{array}$ & Puas \\
\hline
\end{tabular}

Source: Processed primary data, 2021

Responses to responses include employees' responsiveness to consumer complaints, serving quickly, and always being quick in handling consumer transactions expressed satisfaction with an average score of 3.78 in the interval category of 3.41-4.20.

\section{Consumer Response Index on Service Assurance}

Service assurance is knowledge, decency and trustworthy nature owned by the service providers. The results of the response to the service guarantee can be described in Table 8.

Table 8. Consumer Response to Service Guarantee

\begin{tabular}{|c|c|c|c|c|c|c|c|c|c|}
\hline \multirow{2}{*}{ No } & \multirow{2}{*}{ Questions } & \multicolumn{5}{|c|}{ Score } & \multirow{2}{*}{ Total } & \multirow{2}{*}{ Average } & \multirow{2}{*}{ Information } \\
\hline & & SP & $\mathbf{P}$ & $\mathbf{S}$ & TP & STP & & & \\
\hline 1. & $\begin{array}{l}\text { Is employees attentive and } \\
\text { polite in serving consumers }\end{array}$ & 8 & 49 & 3 & 0 & 0 & 245 & 4,08 & Puas \\
\hline 2 & $\begin{array}{l}\text { Do employees have } \\
\text { extensive knowledge of } \\
\text { their products }\end{array}$ & 2 & 20 & 38 & 0 & 0 & 204 & 3,40 & Sedang \\
\hline 3 & $\begin{array}{l}\text { Does wong solo restaurant } \\
\text { have the ability to instill } \\
\text { consumer confidence in the } \\
\text { product }\end{array}$ & 5 & 33 & 21 & 1 & 0 & 222 & 3,70 & Puas \\
\hline 4. & $\begin{array}{l}\text { Do employees serve the } \\
\text { quality of hospitality in } \\
\text { serving consumers }\end{array}$ & 8 & 46 & 6 & 0 & 0 & 242 & 4,03 & Puas \\
\hline 5. & $\begin{array}{l}\text { Does the employee provide } \\
\text { an explanation about the } \\
\text { safety for the product is } \\
\text { halal for consumption by } \\
\text { consumers }\end{array}$ & 2 & 27 & 28 & 3 & 0 & 208 & 3,47 & Puas \\
\hline & $\begin{array}{l}\text { Total } \\
\text { Average }\end{array}$ & & & & & & & $\begin{array}{c}18,68 \\
3,74\end{array}$ & Puas \\
\hline
\end{tabular}

Source: Processed primary data, 2021

Respoden's response to the service guarantee includes employees being able to provide explanations about product safety, halal, attention and politeness, rama tamah serving consumers, as well as restaurant employees wong solo has the ability to instill 
consumer confidence in the product expressed agree, with an average of 3.74 .

\section{Consumer Response Index on Concern (Emphaty)}

Table 9. Consumer Response to Concern (Empathy)

\begin{tabular}{|c|c|c|c|c|c|c|c|c|c|}
\hline \multirow{2}{*}{ No } & \multirow{2}{*}{ Questions } & \multicolumn{5}{|c|}{ Score } & \multirow{2}{*}{ Total } & \multirow{2}{*}{ Average } & \multirow{2}{*}{ Information } \\
\hline & & SP & $\mathbf{P}$ & $\mathbf{S}$ & TP & STP & & & \\
\hline 1. & $\begin{array}{l}\text { Is the employee able to } \\
\text { communicate well to } \\
\text { consumers }\end{array}$ & 5 & 44 & 11 & 0 & 0 & 234 & 3,90 & Puas \\
\hline 2 & $\begin{array}{l}\text { Do employees understand } \\
\text { the wants and needs of } \\
\text { consumers }\end{array}$ & 2 & 25 & 31 & 2 & 1 & 209 & 3,48 & Puas \\
\hline 3 & $\begin{array}{l}\text { Is the availability of } \\
\text { communication services that } \\
\text { are open to consumers } \\
\text { serving the manager. }\end{array}$ & 2 & 28 & 27 & 3 & 0 & 209 & 3,48 & Puas \\
\hline 4. & $\begin{array}{l}\text { Are employees polite to } \\
\text { consumers }\end{array}$ & 1 & 53 & 6 & 0 & 0 & 235 & 3,92 & Puas \\
\hline 5. & $\begin{array}{l}\text { Whether employees pay } \\
\text { good attention to consumers } \\
\text { or their customers }\end{array}$ & 2 & 47 & 11 & 0 & 0 & 231 & 3,85 & Puas \\
\hline & $\begin{array}{l}\text { Total } \\
\text { Average }\end{array}$ & & & & & & & $\begin{array}{l}18,63 \\
3,73\end{array}$ & Puas \\
\hline
\end{tabular}

Source: Processed primary data, 2021

Respoden's response to empathy in Table 13 showed that respondents expressed satisfaction with the care and attention of wong solo restaurant employees with an average score of 3.73. It is influenced by employees understand the wants and needs of consumers, employees can communicate well, politely, and attention to consumers.
Concern (emphaty) shows a statement of concern and concern to consumers individually. The results of the response to concern can be explained in Table 9.

\section{Consumer Satisfaction Response Index}

Satisfaction is a feeling within a person about what has been gained and felt when he becomes a consumer. The results of responses to customer satisfaction can be explained in Table 10.

Table 10. Customer Satisfaction Responses

\begin{tabular}{|c|c|c|c|c|c|c|c|c|c|}
\hline \multirow{2}{*}{ No } & \multirow{2}{*}{ Questions } & \multicolumn{5}{|c|}{ Score } & \multirow{2}{*}{ Total } & \multirow{2}{*}{ Average } & \multirow{2}{*}{ Information } \\
\hline & & SP & $\mathbf{P}$ & $\mathbf{S}$ & TP & STS & & & \\
\hline 1. & $\begin{array}{l}\text { Is comfortable when } \\
\text { employees provide services }\end{array}$ & 9 & 48 & 3 & 0 & 0 & 246 & 4,10 & Puas \\
\hline 2 & $\begin{array}{l}\text { Do like fried chicken at Wong } \\
\text { Solo restaurant }\end{array}$ & 13 & 44 & 3 & 0 & 0 & 250 & 4,17 & Puas \\
\hline 3 & $\begin{array}{l}\text { Is satisfied and dissatisfied } \\
\text { with the attention and service } \\
\text { paid by wong solo restaurant } \\
\text { employees }\end{array}$ & 5 & 47 & 8 & 0 & 0 & 237 & 3,95 & Puas \\
\hline 4. & $\begin{array}{l}\text { Do like with grilled chicken at } \\
\text { Wong Solo restaurant }\end{array}$ & 15 & 43 & 1 & 1 & 0 & 252 & 4,20 & Puas \\
\hline 5. & $\begin{array}{l}\text { Do you like the } \\
\text { complementary miniman } \\
\text { menu at Wong Solo restaurant }\end{array}$ & 11 & 48 & 1 & 0 & 0 & 250 & 4,17 & Puas \\
\hline & $\begin{array}{l}\text { Total } \\
\text { Average }\end{array}$ & & & & & & & $\begin{array}{l}20,59 \\
4,12\end{array}$ & Puas \\
\hline
\end{tabular}

Source: Processed primary data, 2021 
Respoden response in Table 10. showed that most respondents responded satisfactorily to the quality of service provided by Wong Solo restaurant, with an average of 4.12. This is the customer feels comfortable with the service of employees, feel satisfied and happy for the attention given by employees, and likes fried chicken, grilled chicken, and beverage menu served by Wong Solo restaurant

\section{Multiple Regression Analysis}

Multiple linear regression test results for bound variables (Y) and free variables: physical proof (X1), reliability (X2), responsiveness (X3), service assurance (X4), care (X5) are processed using SPSS 15 soft ware. Factors that affect wong solo restaurant service as a provider of processed chicken meat to consumer satisfaction, the results of multiple linear regression calculations as in Table 11.

Table 11. Multiple Linear Regression Analysis Results

\begin{tabular}{|c|c|c|c|c|}
\hline \multirow{2}{*}{ Source variations } & \multicolumn{2}{|c|}{ Unstandardized coefficients } & \multirow{2}{*}{$\mathbf{t}$} & \multirow{2}{*}{ Sig } \\
\hline & B & Std, Error & & \\
\hline Constant & 8.752 & 3.295 & 2.656 & .010 \\
\hline Tangible & -.012 & .150 & -.083 & $.934^{\mathrm{ns}}$ \\
\hline Reliability & -.228 & .115 & -.1978 & $.053^{*}$ \\
\hline Responsiveness & .274 & .164 & 1.675 & $.100^{\mathrm{ns}}$ \\
\hline Jaminan pelayanan & .100 & .141 & 708 & $.482^{\mathrm{ns}}$ \\
\hline Empathy & .497 & .144 & 3.446 & $.001^{* *}$ \\
\hline Koefisien determinasi $\left(\mathrm{R}^{2}\right)$ & 0.391 & & & \\
\hline F- Hitung & $6,936 * *$ & & & \\
\hline
\end{tabular}

Based on Table 11 that the factors that affect wong solo restaurant services as a provider of processed chicken meat to customer satisfaction, has a model formulation of regression equations, namely : $\mathrm{Y}=8.752+(-0,012) \mathrm{X}_{1}+(-0,228) \mathrm{X}_{2}+0,274$ $X_{3}+0,100 X_{4}+0,144 X_{5}+$ e. The results of the analysis showed that the kanstanta value of 8,752 means that customer satisfaction is in the category of intervals are very dissatisfied if there is no treatment: physical evidence (tangible), reliability, responsiveness, service assurance, and empathy. The results showed that the value of the coefficient of determination (R2) of 0.39 means that consumer satisfaction as a bound variable is influenced by free variables in the model of $39 \%$, while the remaining large $61 \%$ is influenced by other variables that are not included in the research variables. The Fcount value of 6,936 is significant at $(\mathrm{P}<0.01)$ means that all free variables include: physical evidence (tangible), reliability, responsiveness, service assurance and empathy together affect the bound variables (consumer satisfaction).

\section{Physical Proof (Tangible) (X1)}

Physical evidence is part of the quality of service. Wong Solo restaurant in the form of attractive building arrangement, spacious and safe parking lot, clean and attractive employee appearance. The results of the regression analysis showed that physical evidence-free variables had no effect and were negatively correlated to consumer satisfaction. The value of physical evidence koefisen of -0.012 means that each addition of physical evidence variables will reduce consumer satisfaction with the quality of service variable reliability, variable responsiveness, variable service guarantee and variable care.

These results are similar to Hardiyah's research (2010) that physical evidence has a positive influence on consumer satisfaction. The better the physical evidence in the restaurant will be the higher the satisfaction of consumers, on the contrary the less good physical evidence that exists in the restaurant, the better also the satisfaction of consumers. 


\section{Reliability (X2)}

Reliability is part of the quality of wong solo restaurant services in the form of employee reliability in serving consumers, service in accordance with consumer expectations, and quickly serve consumer orders. The higher the reliability variable given to consumers, the higher the level of customer satisfaction. This happens because customers feel that the service they get is in line with their expectations.

Reliability variables were negatively correlated to consumer satisfaction, with a coefficient value of -0.228 . This means that each increase in reliability variables will decrease consumer satisfaction with the quality of service variable responsiveness, service assurance and care. Hardiyah research results (2010) stated that the direction of positive regression coefficient means that reliability has a significant positive influence on consumer satisfaction.

\section{Responsiveness (X3)}

Responsiveness is part of the quality of service at Wong Solo restaurant in the form of employees' desire to help customers, employees respond to consumer complaints and always quickly handle consumer transactions. The higher the level of response given, the more customer satisfaction will increase. This is a customer satisfied with the employee's service to the customer in accordance with his expectations.

The results of the regression analysis that the responsiveness variable is positively correlated to consumer satisfaction. The regression coefficient value is 0.274 . This means that the increase in variable tangap power will increase consumer satisfaction.

\section{Service Assurance (X4)}

Service assurance is part of the quality of service at Wong Solo restaurant in the form of consumer opinion knowledge about the products offered, polite service to consumers and trustworthy nature of employees to help consumers. The higher the variable guarantee of service provided to consumers, the higher the level of customer satisfaction.
The results of the regression analysis that service assurance variables are positively correlated to consumer satisfaction. The value of the regression coefficient of 0.1 means that each increase in service guarantee variables also increases consumer satisfaction. Variable service guarantee is low then customer satisfaction will decrease, on the contrary the higher the variable of service guarantee, the higher the satisfaction of consumers wong solo restaurant, Kendari.

Hardiyah (2010) states that the direction of positive regression coefficients then guarantees have a significant positive influence on consumer satisfaction. The greater the guarantee of service provided by employees to consumers, the higher the satisfaction of consumers, on the contrary the lower the guarantee of service provided by employees, the lower the customer satisfaction.

\section{Caring (Empathy) (X5)}

Care is part of the quality of service at Wong Solo restaurant in the form of employee attention to consumers, understanding consumer needs and communicating well to consumers. The results of the regression analysis that the variables of concern are positively correlated and affect the satisfaction of consumers of Wong Solo restaurant $(p<0.01)$. The value of the regression coefficient of caring variable is obtained 0.497 , meaning that any increase in the caring variable will increase consumer satisfaction. High variable care will increase customer satisfaction. On the contrary, the lower the variable concern, the lower the customer satisfaction.

\section{CONCLUSIONS AND SUGGESTIONS}

\section{Conclusion}

Based on the results of the discussion, it is concluded that:

1. Free variables such as: Physical evidence, reliability, responsiveness, service assurance, and care together have a very real effect on customer satisfaction at Wong Solo restaurant in Kendari City $(\mathrm{p}<0.01)$. Factors that are 
positively correlated to consumer satisfaction are responsiveness, service assurance and care, while variables that correlate negatively to consumer satisfaction are evidence of physicality and reliability.

2. Variable concern partially affects consumer satisfaction $(\mathrm{P}<0.01)$

\section{Suggestion}

It is recommended that there be further research that includes variable quality of service (free variables) in addition to variables: physical evidence, reliability, responsiveness, service assurance, and concern for consumer satisfaction (bound variables) such as product price variables, product jumlan and worship advice so that it is expected to obtain a higher coefficient of determination.

\section{REFERENCES}

Alma. 2002. Manajemen Pemasaran dan Pemasaran Jasa. Alfabeta. Bandung.

Amstrong, G dan Kolter Philip.1997. Cetakan Prinsip-prinsip Pemasaran pertama. Erlangga. Jakarta.

Anggraini, S. 2010. Analisis Persepsi dan Preferensi Konsumen terhadap Produk Daging Olahan Beku di Kota Bogor. Institut Pertanian Bogor. Bogor.

Anonim. 2008. Nilai Gizi Ayam Kampung. http://giziku-ayamkampung.com. diakses pada bulan 5 Mei 2015.

Badan Pusat Statistik. 2014. Laporan Produksi Daging Ayam Sulawesi Tenggara. Kendari.

Bruce, A, Chadwick, Bahr, M, Howard, Albrecht, Stan, L. 1984. Merode Penelitian Ilmu Pengetahuan Sosial. Terjemahan. Sulistia, Yan Mujianto, Sofwan Ahmad, dan Suhadrjito. IKIP Semarang Press. Semarang.

Effendy. 1982. Marketing Management. Institut Management Widya Gama. Malang.

Fitrian, N. 2010. Analisis Pengaruh Kualitas Produk dan Kualitas Layanan Terhadap
Keputusan Pembelian: skripsi. (Diakses tanggal 5 Mei 2015).

Hadini, H,A, S, Nurtini, dan E,Sulastri. 2011. Analisis permintaan dan prediksi konsumen serta produksi daging bloiler di Kota Kendari. Buletin Peternakan Vol. 35 (3):202-207.

Hardiyah, Ratih. 2010. Analisis pengaruh kualitas pelayanan terhadap kepuasan konsumen menggunakan jasa penginapan (villa) AgroWisata Kebun The Pagilaran. Skripsi. Fakultas Ekonomi Universitas Diponegoro. Semarang.

Irawan, H. 2004. Sepuluh Prinsip Kepuasan Pelanggan. Paradigma Baru Merebut Hati Pelanggan Untuk Menekan Persaingan. PT Elex Media Komputindo Kelompok Gramedia. Jakarta.

Keputusan Menteri Pendayagunaan Aparatur Negara. No 25 Tahun 2004. Tentang Pedoman Penyusunan Index Kepuasan Masyarakat Unit Pelayanan Instansi Pemerintah. Jakarta.

Kolter, P. 2000. Manajemen Pemasaran. Edisi Milenium Jilid 1. PT Prenhallindo. Jakarta.

Kolter, P. 2002. Manajemen Pemasaran di Indonesia. Analisis Perencanaan. PT Prenhallindo. Jakarta.

Kotler, Philip. 2005. Manajemen Pemasaran Jilid 1 (11th ed.) (Benyamin Molan, Penerjemah). PT. Indeks. Jakarta.

Kotler, Philip. 2007. Manajemen Pemasaran. Penerbit. Erlangga. Jakarta.

Larwie. R.A.1995. Ilmu Daging. Edisi Kelima. Terjemahan. A. Parakassi. Dan Y. Amwila. Universitas Indonesia Press. Jakarta.

Lupioyoadi, Rambat dan A. Hamdani. 2006. Manajemen Pemasaran Jasa. Penerbit Salemba Empat. Jakarta.

Pappas, J.L dan M. Hirschey.1995. Ekonomi Manajerial. Terjemahan Edisi Keenam, Jilid 1. Binarupa. Angkasa. Jakarta.

Putong. 2003. Pengantar Ekonomi Mikro dan Makro. Ghalia Indonesia. Jakarta. 
Rangkuti. 2004. Analisis SWOT Teknik Membeda Kasus Bisnis. Garamedia Pustaka. Jakarta.

Rondonuwu, Giofany. 2014. Tingkat kepuasan konsumen di restoran MC Donald's Manado. Jurnal. Fakultas Pertanian Universitas Samratulagi. Manado.

Setyawan, Yusuf. 2008. Kualitas pelayanan (Service Quality) terhadap kepuasan konsumen rumah makan Ayam Bakar Wong Solo. Cabang Malang. Skripsi. Fakultas Peternakan Universitas Brawijaya. Malang.

Simamora. 2002. Riset Perilaku Kosumen. PT. Gramedia Pustaka Utama, Jakarta.

Singarimbun, M. 1989. Metode Penelitian Survei. LP3ES. Jakarta.

Soedjana. T.D. 1996. Perkembangan Konsumsi Daging Dan Telur Di Indonesia. Majalah Pangan No 29 Vol VII. Bogor.

Sudjana. 2003. Teknik Analisis Regresi dan Korelasi Bagi Peneliti. Tarsito. Bandung.

Sugiyono. 2004. Statistik Untuk Penelitian. Alfabeta. Bandung

Sugiyono. 2009. Metode Penelitian Bisnis. CV. Afabeta. Bandung

Sukirno. 2005. Mikro Ekonomi Teori Pengantar. PT Raja Graha Persada. Jakarta.

Sumarno. 2007. Ekonomi Mikro. PT Graha Ilmu. Yogyakarta.

Sumarwan, U. 2003. Prilaku Konsumen Teori dan Penerapan Dalam Pemasaran Penerbit Gralia Indonesia. Jakarta.

Tjiptono, F. 1997. Manajemen Jasa. Andi Offset. Yogyakarta.

Tjiptono, F. 2007. Strategi Pemasaran. Edisi Pertama. Andi Offset. Yogyakarta.

Tjiptono, F. 2005. Service, quality and satisfaction. Andi offset. Yogyakarta.

Umar, Husein. 2002. Riset Pemasaran dan Prilaku Konsumen. PT Gramedia Pustaka Utama. Jakarta.
Wirahady, N. 2007. Skripsi Analisis Beberapa Faktor yang Mempengaruhi Jumlah Pembelian Daging Sapi pada Konsumen di Makassar Mall, Makassar. FAPET UNHAS. Makassar.

Yusuf, T. 2000. Unggul dalam Menjual. PT Alex Gramedia Komputindo Jakarta. 